\title{
CONSTITUTIONAL LAW: SUPREME COURT HOLDS PENNSYLVANIA STATUTE IMPOSING COSTS ON AN ACQUITTED DEFENDANT VOID FOR VAGUENESS
}

\begin{abstract}
In sustaining the defendant's vagueness challenge, the Supreme Court rejected the State's contention that since the statute was "civil" in character, it did not have to meet the due process standard of certainty required of criminal statutes. The Court's language is susceptible of varying interpretations which, in turn, give rise to possibilities for novel applications of the void-forvagueness doctrine.
\end{abstract}

$I_{\mathrm{N}}$ Giaccio v. Pennsylvania, ${ }^{1}$ the defendant was acquitted of two charges brought under a Pennsylvania statute making it a misdemeanor wantonly to point or discharge a firearm at another person. ${ }^{2}$ Pursuant to instructions of the court and in accordance with a state statute, ${ }^{3}$ the jury assessed court costs against him for one of the charges. ${ }^{4}$ This statute provided in part that "in all cases of acquittals by the petit jury on indictments for [offenses other than felonies] . . . the jury trying the same shall determine, by their verdict, whether the county, or the prosecutor, or the defendant shall pay the costs...."

The Pennsylvania Supreme Court affirmed the imposition of costs and upheld the statute, characterizing it as "civil" rather than "penal" in that it provided machinery for the imposition of costs "not as a penalty but rather as compensation to a litigant for expenses." 6 Thus, the ascertainable standards of guilt required of penal statutes by the due process clause of the fourteenth amendment ${ }^{7}$ were not regarded as essential to the -validity of this "civil"

1382 U.S. 399 (1966).

3 Pa. Stat. ANn. tit. 18, § 4716 (1963).

${ }^{3}$ Pa. Stat. ANN. tit. 19, § 1222 (1963).

+382 U.S. at 400.

- PA. Stat. ANN. tit. 19, § 1222 (1963). The statute also provides: "whenever the jury shall determine as aforesaid, that the prosecutor or defendant shall pay the costs, the court in which the said determination shall be made shall forthwith pass sentence to that effect, and order him to be committed to the jail of the county until the costs are paid, unless he give security to pay the same within ten days." Ibid. (Emphasis added.)

- Commonwealth v. Giaccio, 415 Pa. 139, 144-45, 202 A.2d 55, 58.59 (1964).

- If a criminal statute fails to define the conduct which it makes punishable, it may be declared void for vagueness on the ground that it is inconsistent with due 
statute. ${ }^{8}$ However, the United States Supreme Court reversed and declared that whatever label was given the act, it provided the state with a procedure for depriving an acquitted defendant of his liberty or property and that such a statute must meet the challenge that it is unconstitutionally vague. ${ }^{9}$ The statute was held unconstitutional as written because it was "so vague and standardless that it leaves the public uncertain as to the conduct it prohibits or leaves judges and jurors free to decide, without any legally fixed standards, what is prohibited and what is not in each particular case."10

process of law to mete out punishment without fair notice to those whose conduct may subject them to sanction. E.g., Winters v. New York, 333 U.S. 507, 520 (1948); Lanzetta v. New Jersey, 306 U.S. 451, 458 (1939); Connally v. General Constr. Co., 269 U.S. 385, 391, 395 (1926); Jordan v. DeGeorge, 341 U.S. 223, 230 (1951) (dictum). Moreover, a criminal statute must provide standards adequate to guide the court and jury in determining whether particular conduct falls within the statutory prohibition. See United States v. Petrillo, 332 U.S. 1, 7 (1947); Screws v. United States, 325 U.S. 91, 151-52 (1945) (dissenting opinion); Cf. Beauharnais v. Illinois, 343 U.S. 250, 264 (1952). See generally Collings, Unconstitutional Uncertainty-An Appraisal, 40 CoRnell L.Q. 195 (1955); Note, Due Process Requirements of Definiteness in Statutes, 62 HARv. L. REv. 77 (1948).

The trial court had held that the statute was a punitive measure and that, as such, it failed to meet the requirements of the due process clause of the fourteenth amendment, for it failed to give notice of the conduct it punished. Commonwealth v. Giaccio, 30 Pa. D. \& C.2d 463, 468.69 (Q.S. Chester 1963). However, the Superior Court reversed, holding that the imposition of costs did not constitute punishment for the commission of a crime. Commonwealth v. Giaccio, $202 \mathrm{~Pa}$. Super. 294, 306, 196 A.2d 189, 195 (1968). The Pennsylvania Supreme Court stressed that the statute was "civil in nature" and did not create an offense without properly defining the prohibited conduct. Commonwealth v. Giaccio, 415 Pa. 139, 145, 202 A.2d 55, 59 (1964).

382 U.S. at 402. See, e.g., Jordan v. DeGeorge, 341 U.S. 223, 231 (1951) (statute met void-for-vagueness requirements); Minnesota ex rel. Pearson v. Probate Court, 309 U.S. 270, 274 (1940) (same); Fleuti v. Rosenberg, 302 F.2d 652, 655 (9th Cir. 1962) (statute invalidated as void for vagueness), vacated and remanded on other grounds, 374 U.S. 449 (1963).

Not only are statutes by which the state may deprive individuals of liberty or property subject to challenge, but also subject to attack are statutes which proscribe conduct which will give rise to private rights of action for injury caused by the prohibited conduct. See Old Dearborn Distrib. Co. v. Seagram-Distillers Corp., 299 U.S. 183 (1936), where a fair trade law was sustained over a vagueness objection to provisions which recognized a private right of action for damage caused by the sale of "any commodity" in "fair and open competition" at a price below that stipulated by contract. Accord, Baltimore \& O.R.R. v. Groeger, 266 U.S. 521 (1925) (statute requiring locomotive boilers to be "in proper condition and safe to operate" held to prescribe a sufficiently definite standard of duty).

10382 U.S. at $402-03$.

The void-for-vagueness doctrine has also been extensively applied to statutes affecting the exercise of first amendment freedoms. However, there is an additional inquiry in this area, for the vagueness in such statutes is also violative of substantive due process. Where the defect is procedural, the state is not without power to prohibit the conduct which is deemed unlawful but the means selected violate due process by failing to furnish adequate notice and adjudicative standards. See Lanzetta v. New Jersey, 306 U.S. 451 (1939). Where the defect is substantive, the state in pro- 
The Court also rejected the State's contention that any vagueness in the statute had been cured by subsequent state court interpretation. ${ }^{11}$ The Pennsylvania courts had construed the statute as permitting the assessment of costs where the defendant, although not guilty of the offense charged, had engaged in conduct "reprehensible in some respect," "improper," "outrageous to "morality and justice," " or where, notwithstanding his acquittal, the defendant's "innocence may have been doubtful." 12 The Court maintained that such judicial standards nevertheless were so vague as to leave jurors free to determine "the crucial issue upon their own notions of what the law should be instead of what it is." ${ }^{13}$ The Court noted that it would he almost impossible for a person to prepare a defense against such abstract charges as "misconduct," or "reprehensible conduct." If such terms were used in a statute which imposed "forfeitures, punishments or judgments for costs," the Court indicated that such "loose and unlimiting" language would certainly prevent the statute from meeting the requirements of the due process clause. Thus, such terms could not suffice to make valid a statute which, standing alone, was void for vagueness. ${ }^{14}$

The two concurring justices viewed the statute as violative of the most fundamental concept of due process in that it permitted the jury to punish a defendant after finding him not guilty of any offense charged. ${ }^{15}$ The majority chose instead the void-for-vagueness rationale, which does not deny the state the power to impose costs

hibiting harmful conduct has framed the statute in terms so broad that it prohibits or may prohibit conduct which is constitutionally protected and which, thereforc, the state is without power to make punishable. See, e.g., Cox v. Louisiana, 879 U.S. 586 (1965); Baggett v. Bullitt, 377 U.S. 360 (1964); Cramp v. Board of Pub. Instruction, 868 U.S. 278 (1961); Thornhill v. Alabama, 810 U.S. 88 (1940). See generally Collings, supra note 7, at 196-97. But see Note, 109 U. PA. L. REV. 67, 75-85 (1960). 11382 U.S. at 403.

${ }^{12}$ Id. at 404 . The trial court further limited the grounds upon which costs could be imposed by charging the jury that if the defendant had been "guilty of some misconduct less than the offense charged but nevertheless misconduct of some kind as a result of which he should be required to pay some penalty short of conviction [and] ... his misconduct has given rise to the prosecution," the costs of prosecution could be assessed against him. Ibid.

1s Id. at 403 .

16 Id. at 404. But see Nash v. United States, 229 U.S. 373 (1913) ("rule of reason" construction of the Sherman Act sustained over a void-for-vagueness challenge).

15382 U.S. at 405 (concurring opinions of Stewart, J., and Fortas, J.). The trial court had noted that the statute seemed to violate due process "substantively" by im. posing a punishment or penalty upon a defendant found to be innocent under the law. Commonwealth v. Giaccio, $30 \mathrm{~Pa}$. D. \& C.2d 463, 470 (Q.S. Chester 1963). 
upon an acquitted defendant but does require the provision of adequate standards for notice and adjudication. ${ }^{16}$

The majority's reasoning is amenable to varying interpretations which hold different implications for potential applications of the void-for-vagueness doctrine. In its most narrow aspect the opinion could evidence the Court's belief that the imposition of costs upon an acquitted defendant (with the added sanction of imprisonment for failure to pay) is penal in effect, whether the statute is labeled "civil" or "penal."17 Thus, affixing the "civil" label could not serve to foreclose the inquiry into the adequacy of the standards under which penal sanctions could be imposed. ${ }^{18}$ However, the Court's language more readily supports the premise that any statute which provides for the deprivation of liberty or property ${ }^{19}$ must have that certainty of standard required of penal statutes. As a variation

${ }^{20}$ While the majority does not deny the state the power to assess costs against an acquitted defendant, the practical effect of the holding is the same as that of the concurring opinions. It is difficult to envision a statute which could be drafted so as to improve upon the trial court's charge (see note 12 supra) without defining all of the possible acts which could give rise to a misdemeanor prosecution. Thus, even though the state is not without power to impose costs upon an acquitted defendant, the majority furnishes no guidelines for drafting a statute for this purpose which would satisfy due process requirements of certainty. Compare Niemotko v. Maryland, 340 U.S. 268, 284-85 (1951) (concurring opinion).

Local prosecuting attorneys approved of the trial court's holding, for the statute permitted juries to compromise their verdicts. Defense counsel invariably included in their closing argument the observation that the defendant might be punished without finding him guilty by assessing costs against him. Letter from A. Alfred Delduco, Chester County District Attorney, to the Duke Law Journal, March 11, 1966.

17 382 U.S. at 402 . Whatever label is given the statute, it provides the state with a procedure for depriving a defendant of his liberty or property and in this case, where the defendant has been acquitted, the imposition of costs for "some misconduct," id. at 404, constitutes punishment for an offense the elements of which are undisclosed to the defendant or the jury. The Court asserted that the due process protection afforded criminal defendants cannot be denied merely because of the "label a state chooses to fasten upon its conduct or its statute." Id. at 402 . See $26 \mathrm{U}$. PITT. L. REv. 682 (1965).

${ }^{18}$ Under this reading it might be argued that any judicial proceeding which might result in a judgment might be subject to a vagueness challenge, since refusal to comply could result in a contempt citation and imprisonment or fine. However, the Court's language could be restricted to the peculiar facts of the Giaccio case, where the additional sanction was imposed in a criminal proceeding after the defendant had been acquitted of all the charges against him.

10 The United States Supreme Court has entertained void-for-vagueness challenges against noncriminal statutes. See note 9 supra. Likewise, the Ninth Circuit held unconstitutionally vague a statutory provision authorizing the deportation of any alien found to have had a "psychopathic personality" at the time of entry into the United States. Fleuti v. Rosenberg, 302 F.2d 652 (9th Cir. 1962), vacated and remanded on other grounds, 374 U.S. 449 (1968). 
of this interpretation, it might be argued that even though criminal statutes must be more precise than those which impose civil forfeitures, the latter must nevertheless meet some minimal due process standards of certainty where individuals may be deprived of liberty or property.

Whatever the traditional distinction between civil and penal statutes might connote, the degree of certainty required may be a function of the magnitude of the sanction imposed. Thus, it might be asserted that a statute under which small fines were imposed to ensure observance would not be subject to as strict a requirement of certainty as would a statute under which long prison terms were imposed.20 A vague definition of the conduct prohibited by the latter statute would be more objectionable from the standpoint of both the severity of the forfeiture involved and the social stigma which accompanies such a sanction. However, to grant that the standard of certainty is less rigorous for a statute imposing a lesser sanction is not to say that such a statute will be completely immune from a vagneness challenge. Giaccio appears to shift the inquiry from the purpose of the statute to its operative effect in subjecting individuals to deprivations which they might have avoided under a sufficiently precise standard. Thus, a statute characterized as "civil" because of its nonpenal purpose would, nevertheless, be subject to a vagueness challenge if it conditioned the continued enjoyment of prescribed rights upon the observance of ill-defined standards of conduct. ${ }^{21}$

The most narrow interpretation of the opinion, which views the imposition of costs upon an acquitted defendant as penal and thus subject to a stricter vagueness requirement, would have but limited application, for Pennsylvania is the only state which authorizes the

${ }^{20}$ See Winters v. New York, 333 U.S. 507 (1948); Note, 109 U. PA. L. REv. 67, 69-70 n.16 (1960). "The standards of certainty in statutes punishing for offenses is [sic] higher than in those dependent primarily upon civil sanction for enforcement." 333 U.S. at 515 (dictum).

${ }^{31}$ The Court rejected the argument that the civil-penal distinction was dispositive of the question of whether a statute must meet the due process requirement of certainty (see note 9 supra and accompanying text) and indicated that whether a statute imposed "forfeitures, punishments or judgments for costs," it would be amenable to a vagueness challenge if its terms were too "loose and unlimiting." 382 U.S. at 404 . Thus, it is not the penal purpose of a statute which makes it subject to a vagueness objection; rather, it is the fact that it may operate to deprive individuals of their liberty or property for conduct which is not sufficiently de. limited. 
assessment of costs against an acquitted defendant. ${ }^{22}$ Under the broader readings, the language which seems to equate "forfeitures," "punishments" and "judgments for costs" in discussing the inadequacy of such standards as "misconduct" or "reprehensible conduct" $^{23}$ could provide authority for vagueness challenges to state occupational licensing statutes. These statutes generally provide for the refusal, suspension or revocation of licenses on the grounds of "gross immorality,"24 "untrustworthiness or incompetency"25 or "unprofessional conduct."26 Most licensing statutes also list specific grounds for revocation which relate to the occupational fitness of the professional practitioner, such as "conviction of a crime an essential element of which is dishonesty or fraud" 27 or "gross malpractice resulting in permanent injury or death."28 However, such statutes also include one or more of the vague, catch-all phrases mentioned above. ${ }^{29}$ If the vague provision were the sole ground for revocation and the practitioner had a legitimate doubt as to its applicability

\footnotetext{
${ }^{22}$ Commonwealth v. Giaccio, 30 Pa. D. \& C.2d 463, 470 (Q.S. Chester 1963). Of
} course, the decision would discourage enactment of similar statutes in other states and serve as a warning that the void-for-vagueness doctrine is still a viable concept in administration of criminal justice.

s3 382 U.S. at 404 . See note 21 supra and accompanying text.

at E.g., Arr. Stat. ANn. § 72-907 (1957) (osteopath); Cal. Bus. \& Prof. Code § 1680 (8) (dentist).

The Supreme Court has held that "a state cannot exclude a person from the practice of law or any other occupation in a manner or for reasons that contravene the Due Process ... Clause of the Fourteenth Amendment." Schware v. Board of Bar Examiners, 353 U.S. 232, 238-39 (1957). Thus, if a statutory provision were so vague as to furnish the practitioner with insufficient notice that his conduct would constitute grounds for revocation, the procedure by which his license was revoked would seem inconsistent with the fourteenth amendment guarantee of due process. See 15 Hastincs L.J. 339 (1964); text accompanying note 21 supra.

${ }^{25}$ E.g., ARK. STAT. ANN. \$ 7i-91I (4) (1957) (embalmer and funeral director); N.Y. ReAl Prop. LAw $\$ 441$ (c) (real estate broker).

${ }^{30}$ E.g., ARR. Stat. ANN. $\$ 72-407$ (1957) (chiropractor); Conn. Gen. Stat. ANN. \$ 20.199 (1958) (optometrist); IlL. REv. STAT. ch. 91, \$ 16 (a) (1965) (physician); cf. text accompanying note 14 supra. See also McMurtry v. State Bd. of Medical Examiners, 180 Cal. App. 2d 760, 4 Cal. Rptr. 910 (Dist. Ct. App. 1960) ("habitual user" held too uncertain a criterion, so physician's failure to file narcotics report not "unprofessional conduct'); Kronholtz v. Connecticut State Bd. of Examiners in Optometry, 21 Conn. Supp. 332, 154 A.2d 619 (Super. Ct. 1959) (optometrist's practicing in the employ of a store held not to constitute "unprofessional conduct").

${ }^{97}$ E.g., ILL. REv. STAT. ch. 1101/2, § 44 (b) (1965) (public accountant); Ilt. Rev. Stat. ch. $1141 / 2, \S 8(\mathrm{~b})$ (1965) (real estate broker).

${ }^{38}$ E.g., ILL. Rev. STAT. ch. 91, § 16 (a) (9) (1965) (physician).

${ }^{20}$ E.g., ARK. STAT. ANN. $\$ 71-911$ (1957) (embalmer \& funeral director); ARK. Stat. ANN. § 72-407 (1957) (chiropractor); Cal. Bus. \& Prof. CODE $§ 1680$ (dentist); ILL. REv. STAT. ch. 91, § 16 (a) (1965) (physician); Ill. REv. STAT. ch. 114 1/2, $\$ 8$ (1965) (real estate broker); N.Y. REAL Prop. LAw $\$ 441$ (c) (real estate broker); see notes 24-26 supra. 
to his conduct, ${ }^{30}$ under the broader interpretations of Giaccio he might challenge the provision as imposing a forfeiture without the certainty of standard required by the due process clause of the fourteenth amendment. As applied to him, the standards of "gross immorality" or "unprofessional conduct" would provide no notice that his conduct was prohibited. In addition the standard is so vague as to leave the licensing board free to decide his case according to its own predilections and to preclude meaningful court review of the administrative decision..$^{31}$

The vagueness objection goes to uncertainty in the definition of conduct for which sanctions may be imposed. However, Giaccio may provide authority for a vagueness challenge to the practice of permitting a jury to determine the nature and extent of the sanction to be imposed, even though guilt be established under a statute which adequately defines the punishable conduct..$^{32}$ In addition to providing notice, a statute must be sufficiently precise to guide jurors in determining whether specific conduct falls within the statutory proscription. ${ }^{33} \mathrm{Mr}$. Justice Stewart warned that much of the majority's reasoning serves to cast constitutional doubt on the

\footnotetext{
${ }^{80}$ These two factors are relevant in determining whether the practitioner has a tenable ground upon which to assert the vagueness objection. If other, more specific statutory provisions were violated (see notes 27-28 supra and accompanying text) the practitioner would have had adequate notice that the prohibited conduct would result in revocation. However, if the vague provision is the sole ground for revocation and the practitioner's misconduct is unrelated to his professional competence, then he may be deprived of his right to practice without notice as to the conduct prohibited. Clearly the term "unprofessional conduct" does convey some notion of the conduct proscribed. This is especially true where custom or the canons of the profession make the vague phrase a word of art with a very definite meaning. However, if the practitioner's conduct does not fall within one of the more specific provisions, he is forced to speculate as to the permissibility of particular activities at the risk of losing his license. Where he has acted in the genuine belief that the prohibition did not apply he is in a stronger position to assert its vagueness.

This application of the void-for-vagueness doctrine is to be contrasted with its use in first amendment cases which deal with statutes which may, by their overbreadth, inhibit constitutionally protected activity. In the latter cases one may invoke the vagueness challenge even though his conduct falls squarely within the statutory proscription. See note 10 supra.

si It might be argued that the presence of a vague provision in an otherwise certain statute could affect the administrator's decision to the prejudice of the practitioner. Although the conduct in question might not clearly fall within the more specific prohibitions, the broad proscription of "unprofessional conduct" might lead the administrator to resolve questionable violations of specific prohibitions against the practitioner on the theory that they are included in the broader proscription and are, therefore, unlawful whether all of the elements of the specific offense are present or not.

sa See note 34 infra.

ss See note 7 supra.
} 
practice of leaving to "the unguided discretion of a jury the nature and degree of punishment" to be imposed upon a convicted criminal defendant. ${ }^{34}$ The majority stated that a law must not be so vague and standardless as to leave "jurors free to decide, without any legally fixed standards," what is or is not prohibited.35 Further, the jury must not be permitted to "make determinations of the crucial issue upon their own notions of what the law should be instead of what it is."36 This language might indicate that guidelines must be furnished to limit the jury's discretion in differentiating conduct deserving of a lesser penalty from conduct deserving of a greater penalty. Otherwise, the conduct for which the defendant might be punished (through an increase in sentence) would be undefined, and the jurors' determination would reflect their definition of what constitutes punishable conduct. It is arguable that the jury's discretion when it acts as the assessor of penalty should be no less subject to conditions and reviewable standards than when it acts as the finder of fact to determine guilt or innocence.

If, despite the majority's disclaimer, ${ }^{37}$ unlimited jury discretion in fixing criminal punishment would be subject to attack, then under those broader readings of Giaccio which require the presence of ascertainable standards in noncriminal statutes imposing forfeitures, the analogous practice in civil cases of leaving punitive damages to the unguided discretion of the jury might also be subject to challenge. ${ }^{38}$ Here, too, the jury is permitted to decide the extent of the defendant's liability according to their own notions of "what the

36 382 U.S. at 405 (concurring opinion). The majority declared its intention not to cast doubt on the practice of leaving "to juries finding defendants guilty of a crime the power to fix punishment within legally prescribed limits." Id. at 405 n.8. Apparently the majority felt that the prescription of maximum and minimum penalties in criminal statutes provided sufficient limitations on the jury's discretion in fixing punishment. However, the tenor of Mr. Justice Stewart's opinion indicates that he might have viewed the majority's condemnation of leaving "judges and jurors free to decide, without any legally fixed standards, what is prohibited and what is not in each particular case," as casting doubt upon jury discretion even where maximum and minimum sentences are prescribed. Id. at 402-03. (Emphasis added.)

${ }^{35}$ Id. at 402.03 .

${ }^{36} I d$. at 403 .

s7 See note 33 supra.

${ }^{38}$ If the maximum-minimum limits on punishment in criminal statutes suffice to save jury discretion in criminal cases from the vagueness challenge, the Giaccio majority might have greater difficulty in upholding jury discretion in punitive damage cases where there are no maximum-minimum limitations imposed. On the other liand, the punitive damage issue arises in "civil" cases which may require less certainty of standard to satisfy due process (cf. text accompanying notes 20-21 supra). 
law should be."'39 Subject to the limitation that the damage award will be set aside if it is grossly excessive, ${ }^{40}$ the jury is left without guidelines to determine whether and on what grounds a greater or a lesser penalty should be imposed.11

Giaccio thus evinces a potential precedential value far greater than the immediate holding might indicate. The Court's rejection of the civil-penal distinction drawn by the Pennsylvania courts suggests possible applications of the void-for-vagueness limitation in many "civil" areas heretofore considered beyond the compass of the due process requirement of certainty. Civil forfeitures, such as exclusion from one's profession, are currently viewed as constituting deprivations which are as severe as some criminal sanctions. ${ }^{42} \mathrm{Re}-$ liance on the civil-penal distinction to determine which statutes must provide sufficiently precise standards will in the future be unjustified, however. While practical considerations militate against requiring legislatures to define all acts which may suffice for forfeiture, a judicial inquiry which posits the requisite degree of certainty as a variable which turns upon the extent of the deprivation sought to be imposed might be a desirable beginning.

\footnotetext{
${ }^{30}$ See note 13 supra and accompanying text.

Although practical considerations may diminish the effectiveness of attempts to impose limitations upon jury discretion, the vagueness concept may motivate judicial or legislative attempts to check jury arbitrariness. While it would be impossible to prescribe all of the factors which should be considered in assessing punishment or punitive damages, some guidelines can be provided. For example, standards to guide the jury's determination in assessing punitive damages in libel actions might include the defendant's willinguess to retract (in jurisdictions where retraction is not a bar to punitive damages), repetition and compounding of the libel, and actual abuse of the plaintiff.

${ }^{\circ}$ See, e.g., Butts v. Curtis Publishing Co., 225 F. Supp. 916 (N.D. Ga. 1964), aff'd, 351 F.2d 702 (5th Cir. 1965); Wanamaker v. Lewis, 173 F. Supp. 126 (D.D.C. 1959); Kern v. News Syndicate Co., 20 App. Div. 2d 528, 244 N.Y.S.2d 665 (1963).

\$1 The conduct left undefined is only that for which a varying penalty might be imposed. The threshold conduct upon which guilt or innocence depends must he adequately defined (see note 7 supra). However, given the majority's condemnation of unlimited jury discretion in making determinations of what is or is not prohibited (see text accompanying notes $34-35$ supra), the adequacy of the definition of conduct which determines the extent of punishment or liability may similarly be open to question.

${ }^{42}$ Exclusion from one's profession may be comparable to the imposition of a criminal sanction with respect to the severity of the deprivation and the dishonor caused by the forfeiture. Compare Mr. Justice Black's dissent in Cohen v. Hurley, 366 U.S. 117, 145-47 (1960), with his majority opinion in Giaccio juxtaposing "forfeitures," "punishments" and "judgments for costs," 382 U.S. at 404.
} 